TITLE:

CONTRIBUTION TO THE EVOLUTION IN THE GENUS STEPHANOSCYPHUS (SCYPHOZOA CORONATAE) AND ECOLOGY AND REGENERATION QUALITIES OF STEPHANOSCYPHUS RACEMOSUS KOMAI

$\operatorname{AUTHOR}(\mathrm{S})$ :

Werner, Bernhard

CITATION:

Werner, Bernhard. CONTRIBUTION TO THE EVOLUTION IN THE GENUS

STEPHANOSCYPHUS (SCYPHOZOA CORONATAE) AND ECOLOGY AND REGENERATION QUALITIES OF STEPHANOSCYPHUS RACEMOSUS KOMAI. PUBLICATIONS OF THE SETO MARINE BIOLOGICAL LABORATORY 1970, 18(1): 1-20

ISSUE DATE:

1970-09-16

URL:

http://hdl.handle.net/2433/175623

RIGHT: 


\title{
CONTRIBUTION TO THE EVOLUTION IN THE GENUS STEPHANOSCYPHUS (SCYPHOZOA CORONATAE) AND ECOLOGY AND REGENERATION QUALITIES OF STEPHANOSCYPHUS RACEMOSUS KOMAI ${ }^{1}$
}

\author{
BERNHARD WERNER \\ Biologische Anstalt Helgoland, Zentralc \\ Hamburg 50, Germany
}

With 10 Text-figures

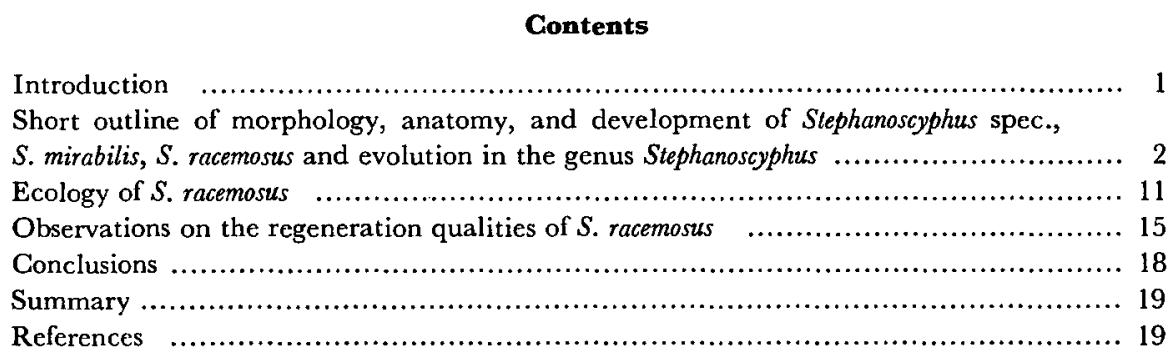

\section{Introduction}

The scyphopolyp Stephanoscyphus represents the polyp generation of the scyphomedusan order Coronatae, and is marked by the firm periderm tube which completely encloses the soft body. Solitary and colonial species belong to this genus. The most knowledge on morphology, anatomy, and life history is based on the papers of Allman (1874) and Komai (1935, 1936) and Komai \& Tokuoka (1939). Allman discovered the Mediterranean species of $S$. mirabilis and has outlined the morphology from living specimens. Lo BIANco \& MAYER (1890) recognized the scyphozoan nature of $S$. mirabilis as they were able to link the strobilating polyp with the medusan genus Nausithoë. KomaI was the first to give a full and adequate description of the morphology and anatomy of the species $S$. racemosus occurring in Japanese waters near Seto.

The previously investigated species $S$. mirabilis and $S$. racemosus represent colonial forms which branch to a high degree. According to the generally accepted opinion, a solitary sessile tetramerous sexual polyp is today believed to be the stem form of all

1) This paper is dedicated to Professor Taku Komat, Kyoto, the famous grand old man of Japanese zoologists who made the first and thorough observations on Stephanoscyphus racemosis. Contributions from the Seto Marine Biological Laboratory, No. 520.

Publ. Seto Mar. Biol. Lab., XVIII (1), 1-20, 1970. (Article 1) 
recent Cnidaria (Remane 1954, Ghapman 1966, Thiel 1966, Ughida 1969, Werner $1970 \mathrm{~b}$ ). Thus, in the class Scyphozoa the true solitary species must be considered as the primitive organisms from which the branched, colonial forms must have originated by secondary steps of evolution. Owing to inadequate knowledge of the solitary species of the genus Stephanoscyphus there was, formerly, no possibility of comparing them with the colonial forms in order to evaluate which were the primary features of the latter and which were developed by progressive evolution.

During the International Indian Ocean Expedition with the German Research Ship "Meteor" in 1964-1965, I was able to collect living specimens of several of the solitary species of Stephanoscyphus. For the first time in the laboratory it was possible to rear these polyps over the complete life cycle. Therefore, the details of the morphology, anatomy and life habits could be investigated (WERnER 1966, 1967 a, b, $1970 \mathrm{a}, \mathrm{b}$ ). The comparison of the solitary and colonial species enables us to follow the steps of evolution in the genus Stephanoscyphus, and to point to the essential signs of morphology and life history of $S$. racemosus dealt with in the following short note on its ecology and regeneration qualities.

S. racemosus, called in Japanese "Iramo", still occurs in abundance near the Seto Marine Biological Laboratory. During a visit to this laboratory in July 1969, I was lucky enough to be supplied with excellent material of living colonies. There was insufficient time to follow the complete life-cycle, in particular the most interesting phase of strobilation. For the planned investigations on propagation to be based on long term rearing experiments it was considered important to see the polyp in its natural habitat, and to complete the knowledge of its ecology. The first experiments have shown that this species exhibits a very high degree of regeneration qualities which are apparently correlated with the colonial habit by ramification.

I am very much indebted to the Director of the Laboratory, Professor H. UTinomi, and particularly to Professor T. TokıокA who supplied me with working space and all the facilities of the station. I am most grateful to Mr. H. TANase, Seto, who was kind enough to collect the wonderful material by diving, and to take troubles of calculating the figures of sea temperature and salinity at Seto to make Table 2. The generous assistance and hospitality of all the Japanese colleagues and all the members of their staffs contributed to make the research visit to Japan a very pleasant experience.

I wish to thank the German Research Council (Deutsche Forschungsgemeinschaft) which generously granted the travel funds and sponsored my work.

\section{Short outline of morphology, anatomy, and development of Stephanoscyphus spec., S. mirabilis, S. racemosus and evolution in the genus Stephanoscyphus}

By rearing several solitary species of Stephanoscyphus collected in the Indian Ocean 
they could be linked with the medusan genus Nausithoë (Coronatae). According to the comparative observations, the systematics of that genus have proved to be difficult because of the great similarities of both the medusan and polyp generations in the several species. Therefore, the definitive systematic work must be temporarily postponed and, for the following comparison with the colonial species one typical solitary species will be presented as $S$. spec. The details of the comparison are given in Table 1. Therefore, it is necessary to give some comments on the points essential from an evolutionary aspect only.

(a) The general habit of the solitary species $S$. spec. (Fig. 1) is characterized by the long slender shape of the tube and its size (up to $80 \mathrm{~mm}$ ). The tube is attached to the substratum by a small basal disc, and its width increases from the narrow base to the terminal aperture. The polyp has a narrow shaped head and the circular mouth field does not very much exceed the width of the tube aperture. There are no zooxanthellae within the white-yellowish coloured soft body. Anatomically, the sack-like thin walled soft body represents the tetramerous structure typical for scyphozoan polyps as it possesses the 4 gastral septa with 4 muscle strands, 4 gastral pockets and the ring canal with 4 radial canals.

(b) In the colonial species S. mirabilis (Fig. $2 \mathrm{a}, \mathrm{b})$ the head of the single polyp has the same shape as in $S$. spec. and also the shape and relative number of tentacles are similar. No zooxanthellae exist and the soft body has a white-yellowish colour. There are no essential differences in anatomical details when compared with the solitary $S$. spec. At first glance, the branching mode of the colony seems to be fairly irregular (Fig. 2 a). The reason is that the conditions of the culture allow the colony to grow freely in all directions. A closer look on a younger colony (Fig. 2 b) shows the mode of branching to be of the racemose type. In free living colonies, embedded in sponges, the mode of ramification is difficult to observe as only the heads of the polyps extend over the surface of the hosts. According to the observations on colonies reared in cultures the complete colony stands on one

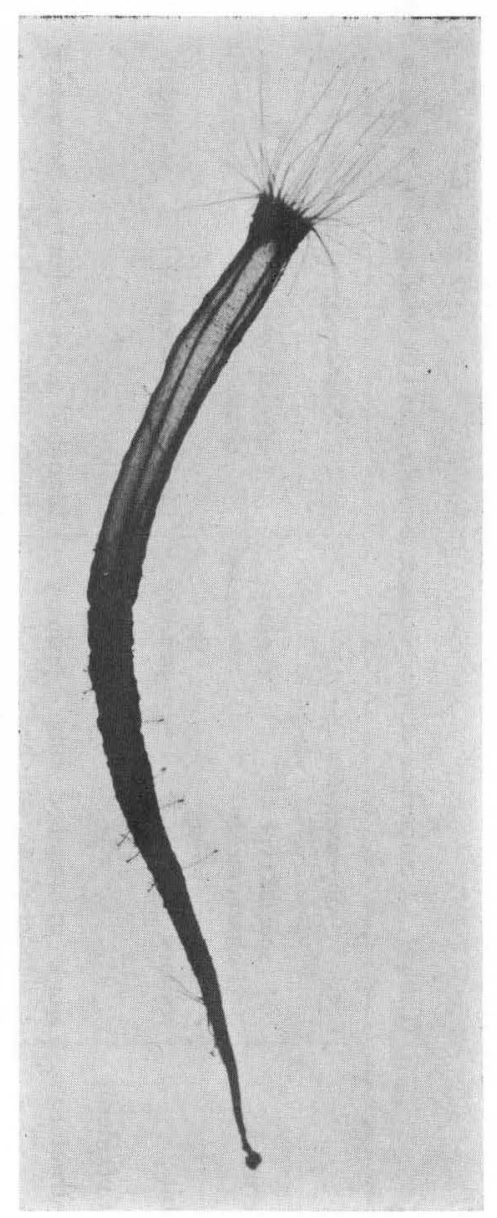

Fig. 1. Stephanoscyphus spec., a solitary tropical species from the Indian Ocean. General shape and habit of the living polyp. From Werner 1966, Fig. 4. 
Table 1. Comparison of morphology, anatomy, and development in the genus Stephanoscyphus

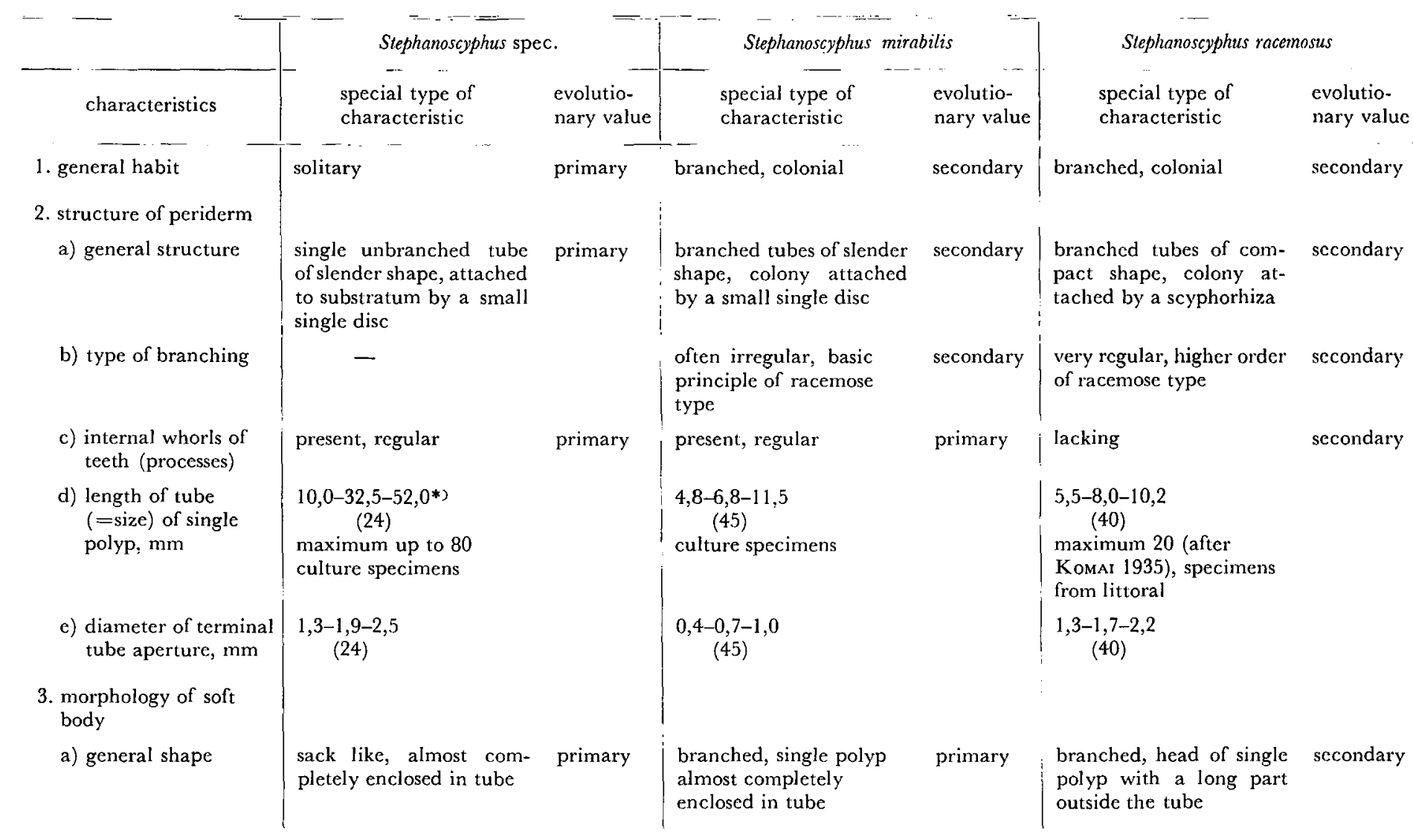


b) shape of head

c) contour of mouth field

d) number, size, and shape of tentacles

e) insertion of gastral septa, hypostome

4. colour of soft body and symbiosis with zooxanthellae

5. anatomy

a) general structure

b) mesogloea

c) gonads

6. development

a) strobilation

b) ephyrae

c) destiny of ephyrae narrow, width little more than diameter of tube aperture

circular

ca. $40-70$, long thin

on mouth, no hypostome i

colourless or white-

yellowish, no symbionts$$
\text { | }
$$

tetramerous by

4 gastral pockets

4 radial canals

4 septal muscles

lacking, resp. present as

thin basic membrane

lacking

regular

small, numerous, unripe

developin medusae primary narrow, as in $S$. spec.

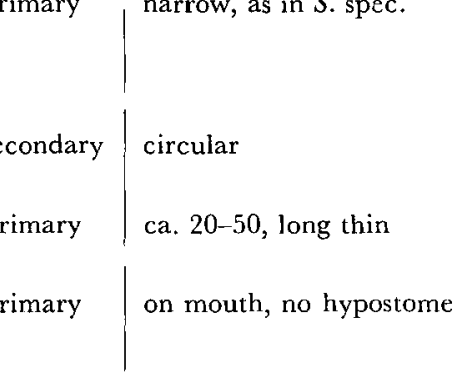

primary j colourless or white-

yellowish, no symbionts

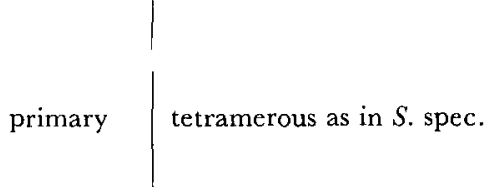

rang

\section{primary}

lacking, resp. present as thin basic membrane

secondary lacking

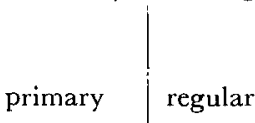

secondary small, numerous, unripe

secondary as in $S$. spec.

as in $S$. spec.

*) the figures give minimum-average-maximum, in brackets number of measurements

\begin{tabular}{|c|c|c|}
\hline primary & $\begin{array}{l}\text { broadened by a rim sur- } \\
\text { rounding the central } \\
\text { mouth field, diameter up } \\
\text { to } 4,3 \mathrm{~mm}\end{array}$ & secondary \\
\hline secondary & $\begin{array}{l}\text { tetramerous by } 4 \text { per- } \\
\text { radial folds of the rim }\end{array}$ & primary \\
\hline primary & $\begin{array}{l}\text { very numerous, up to } \\
200 \text {, short }\end{array}$ & secondary \\
\hline primary & $\begin{array}{l}\text { on mouth, } \\
\text { small cross shaped } \\
\text { hypostome }\end{array}$ & $\begin{array}{l}\text { primary } \\
\text { secondary }\end{array}$ \\
\hline primary & $\begin{array}{l}\text { brown by numerous } \\
\text { zooxanthellae in } \\
\text { endodermal cells }\end{array}$ & secondary \\
\hline primary & $\begin{array}{l}\text { tetramerous by } \\
4 \text { gastral septa } \\
4 \text { gastral pockets } \\
4 \text { radial canals, but } \\
\text { numerous muscle strands }\end{array}$ & primary \\
\hline primary & $\begin{array}{l}\text { lacking, resp. present as } \\
\text { thin basic membrane }\end{array}$ & primary \\
\hline secondary & present & primary \\
\hline primary & regular & primary \\
\hline secondary & $\begin{array}{l}\text { small, numerous, } \\
\text { enclosing ripe germ cells }\end{array}$ & primary \\
\hline secondary & unknown & $?$ \\
\hline
\end{tabular}




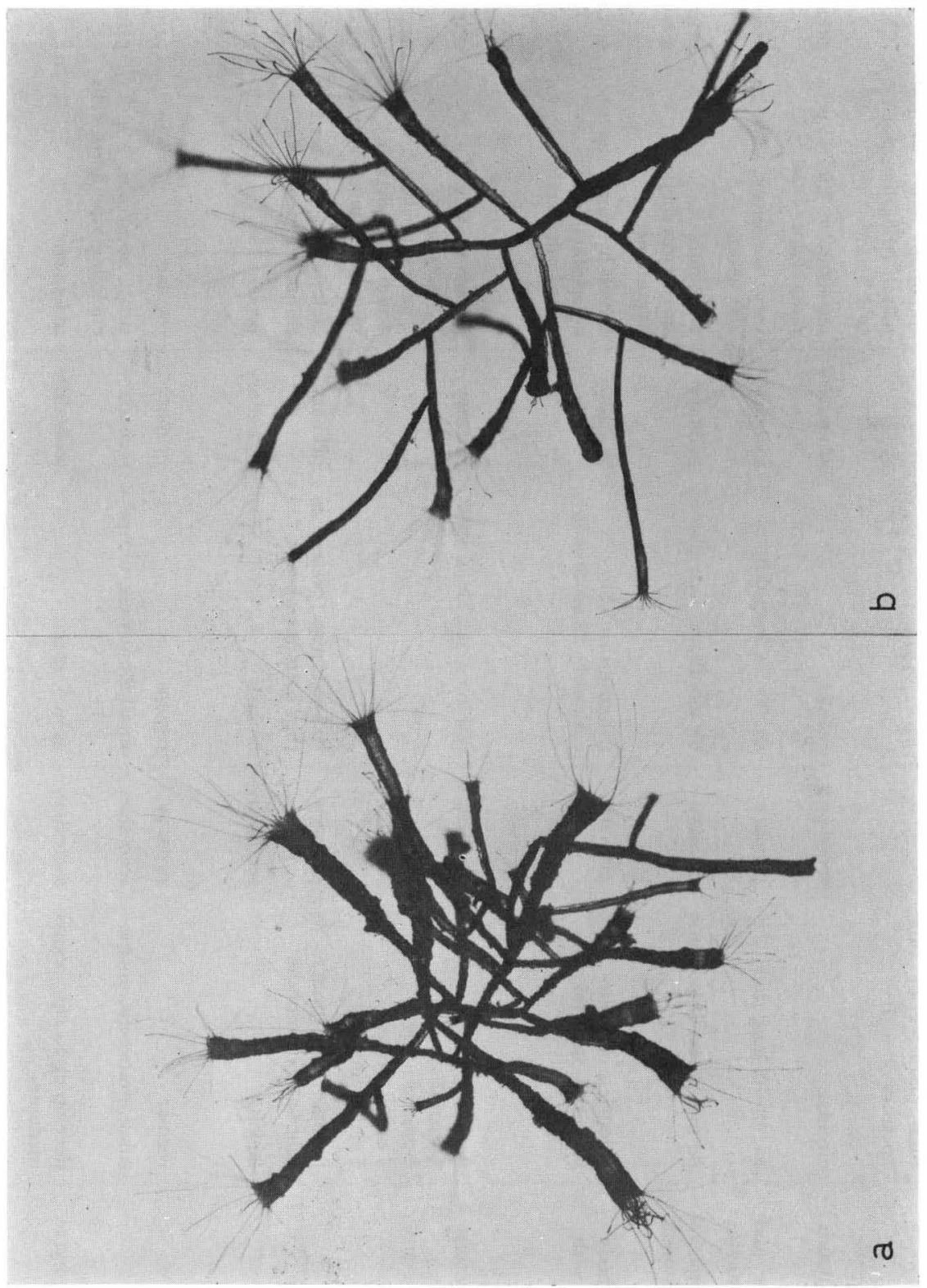

Fig. 2 a,b. Stephanoscyphus mirabilis, a Mediterranean species from the Adriatic Sea, living colonies reared in culture. (a) more dense old colony, (b) young colony showing the racemose type of ramification. 
primary polyp with a single small attaching disc (see below p. 16, Fig. 9).

(c) The colonies of $S$. racemosus are also very often found embedded in sponges. In agreement with the observations of KomaI (1935) there can also be found colonies which grow freely from sponges. Such a colony (Fig. 3) has the regular mode

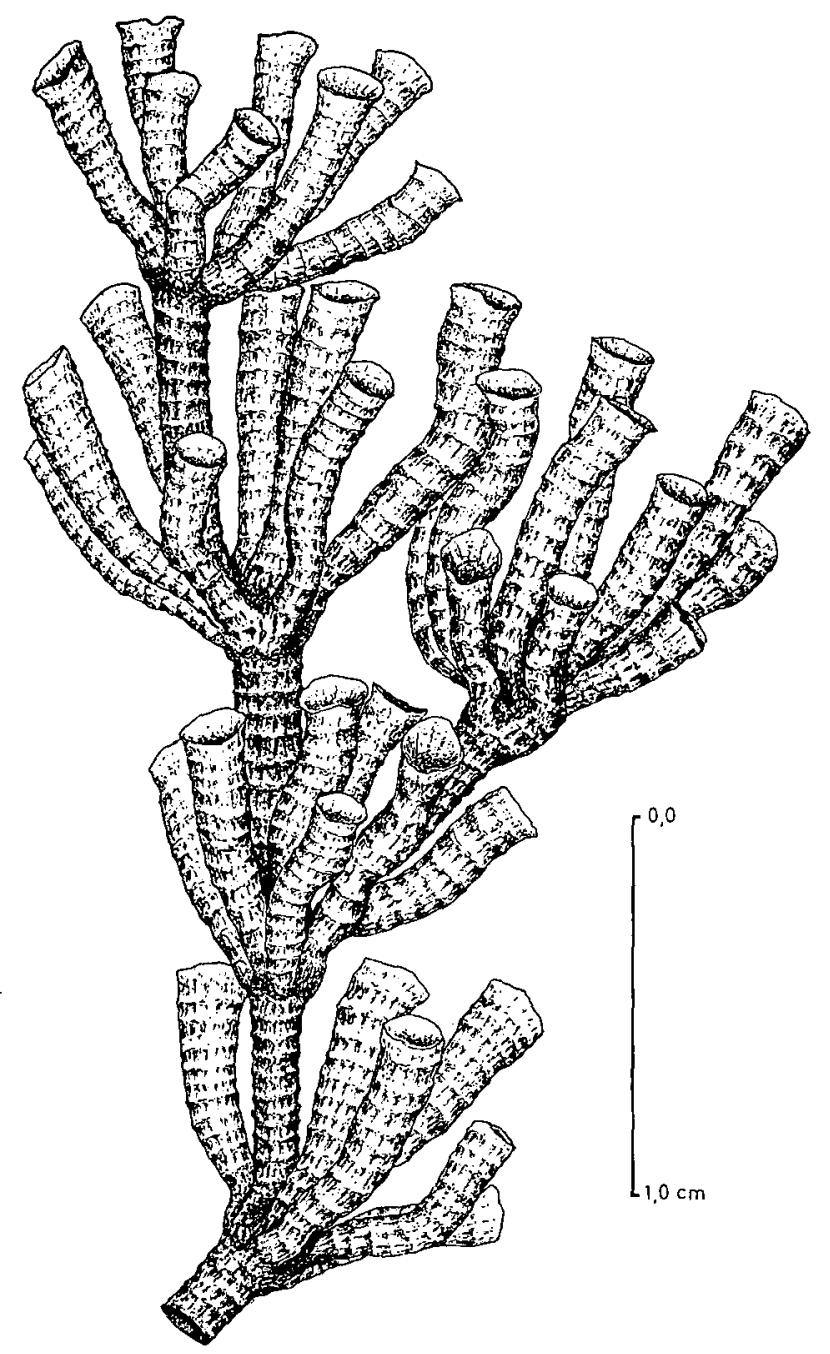

Fig. 3. Stephanoscyphus racemosus, part of a colony with empty tubes, showing the regular order of ramification. Drawn by F. Heckmann.

of ramification as described by Komar. The primary basic polyp is attached to the substratum by a disc. But contrary to $S$. mirabilis, the attaching disc of $S$. racemosus gets enlarged by flat stolonial outgrowths from which new secondary polyps 
can be produced. Thus, S. racemosus possesses a "scyphorhiza" which is homologous to the hydrorhiza of hydroids (see below pp. 15, 17, Figs. 8, 10). The primary basic polyp grows in a more or less vertical direction and has whorls of secondary polyps on several levels, one of which can grow outwards, at an oblique angle, into another principal polyp. It can produce, in the same way of ramification, several new whorls of secondary polyps. This very regular type of ramification by which a colony of $S$. racemosus resembles an inflorescence of the Umbelliferae (KомaI 1935) represents a

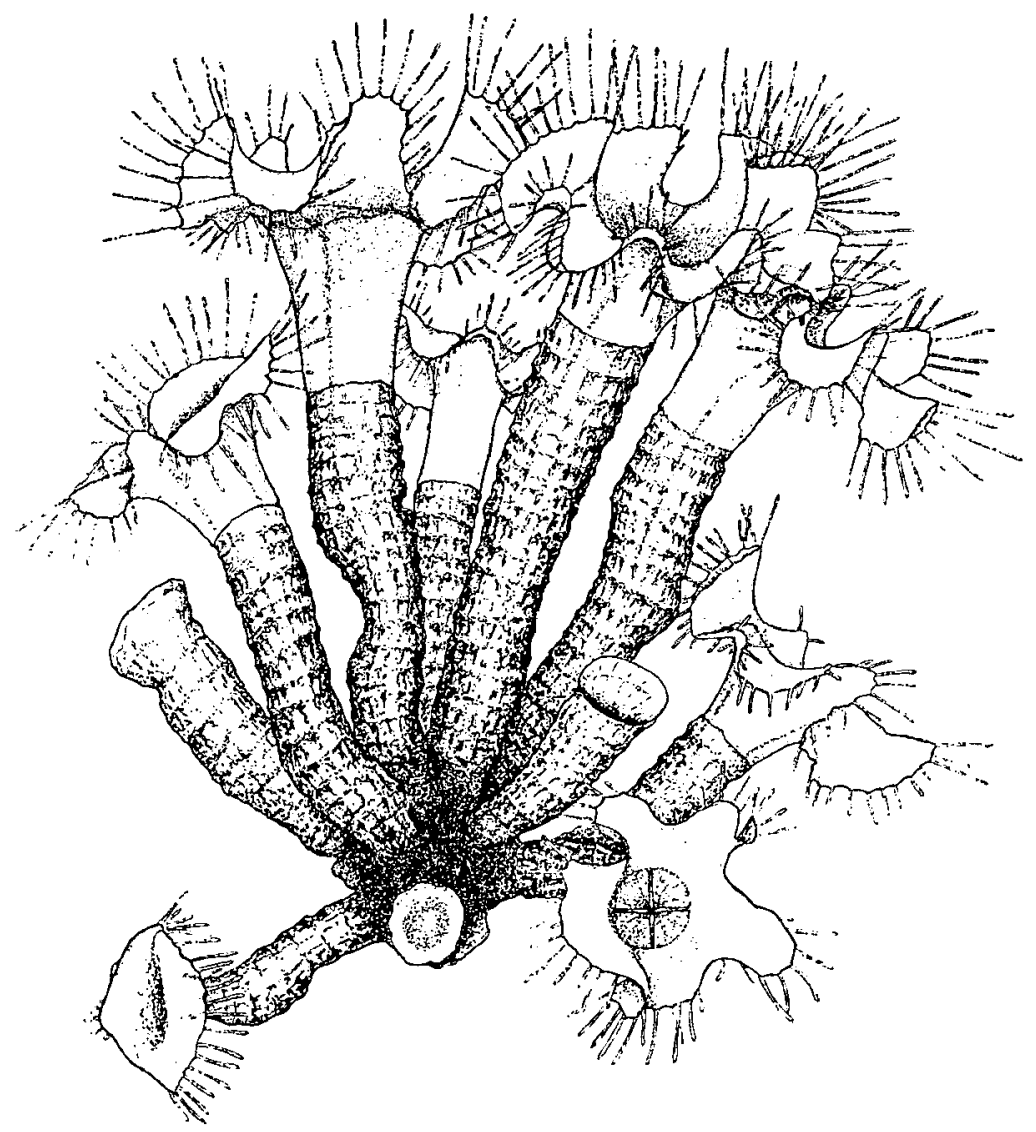

Fig. 4. Stephanoscyphus racemosus, part of a living colony with fully expanded polyps. Drawn by F. HeckmanN.

more advanced stage of order than that found in $S$. mirabilis. The complete colony of $S$. racemosus has a very compact appearance like a colony of corals owing to the regular dense order of numerous polyps and to the thickness of their periderm tubes. Thus, from the point of the morphology of the peridermal structures and the mode of colony formation there can be no doubt that $S$. racemosus represents a true species different from S. mirabilis. 
The same conclusion results from comparison of the morphology of the soft body and its anatomy. The most important morphological characteristic of S. racemosus which distinguishes it from all other known species, is that the head is very much enlarged in length and by a broad rim which surrounds the central mouth field (Fig. 4). This broadened border of the mouth field bears the numerous short tentacles. From the excellent description and drawings of Komai (1935) we know that, apparently, this morphological feature is connected with the possession of brown zooxanthellae situated in abundance in the endoderm of the polyp. This gives the surface of the head the marked brown colour by which the polyps very much resemble brown algae. The inner row of endodermal cells of the tentacles are

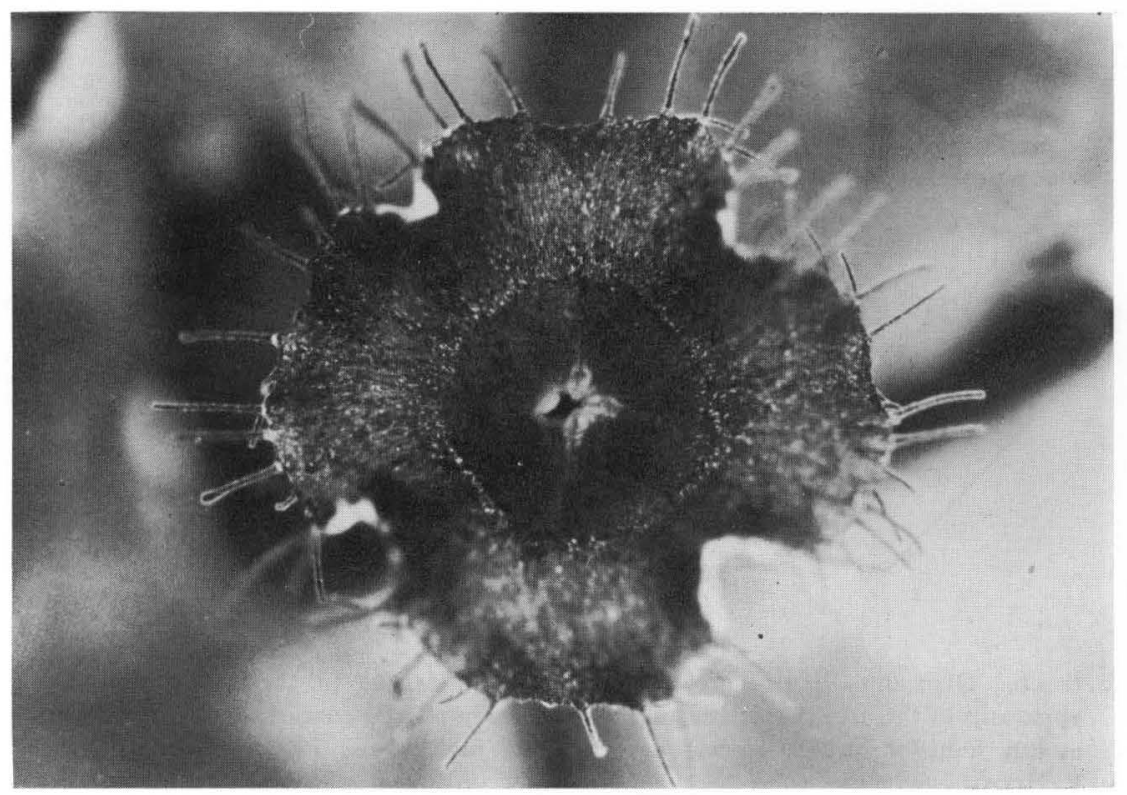

Fig. 5. Stephanoscyphus racemosus, photograph taken from the upper side of mouth field of the living polyp, demonstrating the 4 perradial folds of the border.

brown coloured as the cells are also equipped with zooxanthellae. Apparently, the broadening of the mouth field is to be considered as an adaptation to the symbiosis with the zooxanthellae which need light to grow well.

The broad rim of the mouth field has a peculiar mark which has been illustrated in the drawings of KomaI, but he made no special reference to it. The outer border of the mouth field is bent in on 4 points, so that 4 more or less well developed folds are visible from the upper view (Fig. 5, see also the side-views of Fig. 4). The mouth field has a circular contour but with the 4 folds it presents a marked tetramerous shape. The most interesting point is that the 4 folds are localized exactly in the 
perradii whereas the gastral septa (according to the general terminology) mark the interradii. In polyps embedded in sponges and growing close together, the tetramerous shape of the mouth field can be more or less irregular or not very apparent; however, a comparative investigation of numerous adult polyps growing at some distance from one another, exhibits very clearly the existence of the peculiar tetramerous shape of the mouth field.

It is difficult to explain this structure. As I have mentioned, the broadening of the mouth field must be considered as connected with the possession of zooxanthellae. However, this fact cannot be the reason why the 4 folds of the border of the mouth field are localized exactly in the perradii. Thus, it seems more likely to consider this tetramerous structure to be an old inheritance from the polyp's ancestors, the fossil

a

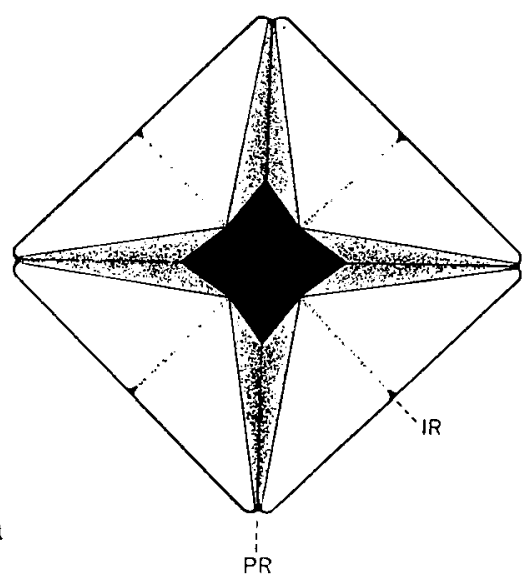

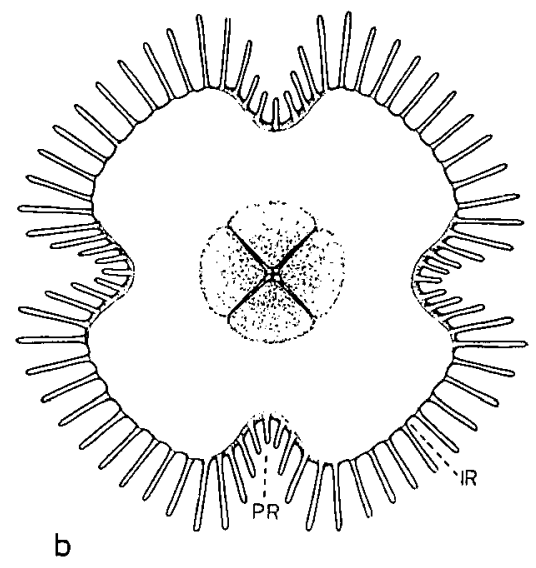
ig. 6 a,b. Diagrammatical comparison of the symmetries: (a) the tetramerous opercular
apparatus of the fossil Conulata, upper view in semiclosed condition; (b) the tetramerous mouth field of Stephanoscyphus racemosus. IR interradius, PR perradius. Drawn by F. Heckmann.

Conulata. It is well known that numerous species of this now extinct group had a tetramerously shaped tube and a closure apparatus of the tube aperture which consisted of 4 triangular flaps (as indicated in Fig. 6 a, see for original drawings Moore \& Harrington 1956, p. F56, Fig. 43). The flaps were bent inwards to close the aperture by means of muscle strands, which are situated in the middle line of the flaps. Therefore, the border of the mouth field of the Conulata must have been bent in between the 4 triangular flaps so that 4 folds must have then originated. It seems likely that in the tetramerous structure of the closing apparatus of the extinct Conulata, we have the key to the special structure of the mouth field of contemporary S. racemosus (Fig. 5, Fig. 6 b).

We know of another special characteristic of $S$. racemosus from the anatomical 
details provided by KomaI. S. racemosus has numerous longitudinal muscles and those in the septa are the largest ones, whereas $S$. spec. and $S$. mirabilis have a muscle system of only 4 muscle strands in the gastral septa. It seems reasonable to explain the increase of muscle number in $S$. racemosus as connected with the enlargment of the head and mouth field. Furthermore, according to present knowledge, S. racemosus represents the only living scyphopolyp which produces germ cells in its body. The sexes are separated. Komai (1935) and Komai \& Tokuoka (1939) have given a most impressive description of the development in which, by the process of strobilation, the germ cells are included in the ephyrae. The actual fate of the ephyrae and germ cells could not be discovered and is still unknown.

I have been formerly inclined (WERNER 1967 a, p. $311 \mathrm{ff}$.) to evaluate this special type of development as an adaptation to the conditions of the special habitat of the high littoral zones in which $S$. racemosus occurs (see below p. 12); but now, by personal knowledge of the living specimens and after confrontation with all peculiarities of this interesting species, there seems to be a possibility of arriving at another explanation. I agree with the view of Komal that the genus Stephanoscyphus, in general, represents a very primitive group of Scyphozoa. If we bear in mind that a sexual sessile polyp is the stem form of all living Scyphozoa and if we take also into account that the development of a separate generation of medusae represents a secondary step of evolution as a means for distribution of the species, the peculiar mode of development in $S$. racemosus can, with good reasons, be considered as an intermediate stage between the ancestral condition and the actual condition in which ripe germ cells are produced from the advanced stage of medusae only. In order to decide, a better knowledge of the complete life cycle is needed. In any case, $S$. racemosus represents, from the point of evolution, a very interesting mosaic of primitive and progressive features. The most outstanding signs of a progressive evolution seem to be the extensive ramification, the formation of a stolonial colony with a scyphorhiza, the enlargement of the head, and the symbiosis with zooxanthellae. From the comparison of the several species it seems to be true that, in the genus Stephanoscyphus, an evolution has taken place from the solitary to the colonial species, and in some ways it is possible to follow the steps of these evolutionary processes.

\section{Ecology of S. racemosus}

At present, the general thesis is true that the shallow seas which border the continents have been the centers for development of life, and in these shallow seas from the first very primitive living organisms a large variety of plants and animals has originated. In furtherance of this opinion there are good reasons for the belief that selectivity and the rate of evolution in the high littoral zones, owing to the harder and more extreme conditions for life, are much more accelerated than in the deeper water layers in which more homogenous general conditions prevail. Comparing the environmental conditions of a habitat on the one hand, and the ecology of 
the living animals with special features of morphological and functional adaptations on the other hand, it should be possible to follow the process of evolution which has taken place.

It appears to be most important to gain more knowledge of the ecology of $S$. racemosus. Komal has already given some interesting and useful observations which we can now complete to some degree. According to present knowledge, most of the solitary species of Stephanoscyphus occur in zones of sublittoral and bathyal. The depth range of the solitary species has been discovered to extend down to 7,000 $\mathrm{m}$ (KRAmP 1959). There also exist some solitary species which occur in the upper zones of the sublittoral (Moore 1961, Brahm \& Geiger 1966). On the other hand, the colonial species must be considered to be true littoral forms as, with regard to present knowledge, their preferred vertical distribution occurs in the higher levels of the sublittoral zones. Of these, $S$. racemosus has, apparently, the highest level in range of vertical distribution. From my own observations and those kindly provided by Professor Tokioka and Mr. TANAse, Seto, some remarks on the horizontal and vertical distribution near Seto can be made. The colonies inhabit the vertical walls or the slopes of rocks and reefs near the boat slide of the Laboratory. Other remarkable points of distribution are: Tosima Island; Fullmoon Islet; the east side of Sisozima Islet; Cape Siono-misaki, the southernmost point of Kii Peninsula; and some points on the coast from Seto to Siono-misaki. In each locality the vertical range is from maximum low water level to about $5 \mathrm{~m}$ below. The average of tidal range is $1.2 \mathrm{~m}$.

In these localities the polyp occurs in very dense colonies. A diver can easily scrape off the colonies from the walls of rocks. From the vertical distribution it is clear, that the polyp inhabits the lighter upper zones of the sublittoral to which is correlated the symbiosis of the zooxanthellae. The restricted area of distribution of $S$. racemosus belongs to the subtropical zone. A level mark of the National Geographical Institute $2.3 \mathrm{~km}$ east from the Laboratory can be noted as the exact point of geographical survey: $33^{\circ} 41^{\prime} 37.5^{\prime \prime} \mathrm{N}, 135^{\circ} 21^{\prime} 56.9^{\prime \prime} \mathrm{E}$.

It is well known that the temperature and salinity are of great importance for the distribution of marine animals. Table 2 gives a short outline of the yearly course of temperature and salinity in Tanabe Bay near the Laboratory. The seasonal fluctuation of temperature is considerable, with average maximum of about $28^{\circ} \mathrm{C}$ in August and average minimum of about $14^{\circ} \mathrm{C}$ in February; a wide amplitude of about $14^{\circ} \mathrm{C}$. In comparison, off the south coast of Arabia (where the solitary species has been found in a depth of about $80 \mathrm{~m}$ ) the temperature ranges over the year from about 20 to $28^{\circ} \mathrm{C}$, giving an amplitude of $8^{\circ} \mathrm{C}$. At Seto the salinity also fluctuates as a result of the summer rain period but the rest of the year a much homogeneous salinity prevails.

From an ecological point of view, the most important and striking phenomenon in the life history of $S$. racemosus is the marked periodicity in the activities. KomaI \& 
Table 2. Monthly maximum, minimum, and average of sea surface temperature and salinity around Seto Marine Biological Laboratory, 1961-1969.

\begin{tabular}{l|ccc|ccc}
\hline \multirow{2}{*}{ month } & \multicolumn{3}{|c|}{$\mathrm{T}^{\circ} \mathrm{C}$} & \multicolumn{3}{|c}{$\mathrm{S} \%$} \\
\cline { 2 - 4 } \cline { 5 - 6 } & maximum & minimum & average & maximum & minimum & average \\
\hline January & 18.5 & 9.8 & 14.4 & 35.26 & 32.36 & 34.37 \\
February & 18.6 & 9.8 & 14.1 & 35.21 & 33.82 & 34.65 \\
March & 18.4 & 11.8 & 15.0 & 36.11 & 32.36 & 34.57 \\
April & 22.5 & 13.5 & 17.6 & 35.55 & 31.37 & 34.27 \\
May & 27.0 & 16.0 & 20.6 & 35.35 & 23.89 & 33.68 \\
June & 28.3 & 19.5 & 23.0 & 35.14 & 25.55 & 33.36 \\
July & 29.0 & 22.6 & 25.9 & 34.81 & 27.57 & 32.45 \\
August & 29.8 & 24.8 & 27.7 & 34.98 & 31.02 & 33.29 \\
September & 29.5 & 21.5 & 26.5 & 34.69 & 30.10 & 33.48 \\
October & 26.5 & 20.6 & 23.3 & 35.46 & 31.38 & 33.76 \\
November & 24.3 & 16.7 & 20.5 & 35.53 & 30.86 & 34.17 \\
December & 21.0 & 14.2 & 17.2 & 35.34 & 32.59 & 34.53 \\
\hline
\end{tabular}

Tокuокa (1939) have observed that strobilae are found only in the month of August, therefore, during the time of highest water temperature. I made a thorough investigation of propagation in the period from 10th to 25th July, 1969. There was no sign of strobilation and the germ cells produced in the polyp were unripe. Furthermore, from personal communications kindly given by Professor SHrino, Tsu, and Professor Tokroka, Seto, I learned the second striking sign of periodical activity as the polyps become reduced in the cold season from January to March. To-day we lack detailed investigations on the morphological and physiological equivalents of this resting and inactive period. Owing to their large size, the colonies must have been built up over several successive years. Therefore, it seems improbable that the colonies of $S$. racemosus are detached from the substratum every year and that they die in the cold season. It is much more probable that the polyps contract into the tubes and undergo a period of reduced metabolism. It is also probable that they close the aperture of the tube by an opercular apparatus which consisis of cell material of the head and a thin periderm membrane secreted by the ectodermal cells of the operculum. The ability to produce such an operculum has frequently been observed during the course of rearing experiments, the first results of which are reported here. In most cases the outside of the opercular apparatus consists of a single thin circular sheet of periderm. However, scmetimes there can be found a funnel shaped external operculum which consists of several sheets of periderm. Apparently, this special structure corresponds to several successive stages of contraction of the soft body into the tube (Fig. 7).

It is known from rearing experiments with other species of Stephanoscyphus that most of them have the same ability to close the tube aperture when required in 
inactive periods and also, as is normal, during the phase of strobilation. However, the existence of such a regular period of inactivity has not been observed in other species. It is well known that a corresponding periodicity occurs in numerous hydroids and species exist which have a period of inactivity during the hot season. This is true in the North Sea for arctic boreal species like Coryne tubulosa (M. SARs). The upper branched parts of the colonies die during the summer and are renewed from the basal stolons at the beginning of the cold season. Thus, the appearance of the medusae in the plankton falls in the cold season. In the same area there exist other species for which the winter represents the period of inactivity resulting in the reduction of the colonies which grow out again in the spring time. In such boreal or southern boreal species the medusae are known to occur during the summer. $S$. racemosus must be grouped with a similar category in which the period of inactivity takes place in the winter. If we seek the reason for the development of such a striking

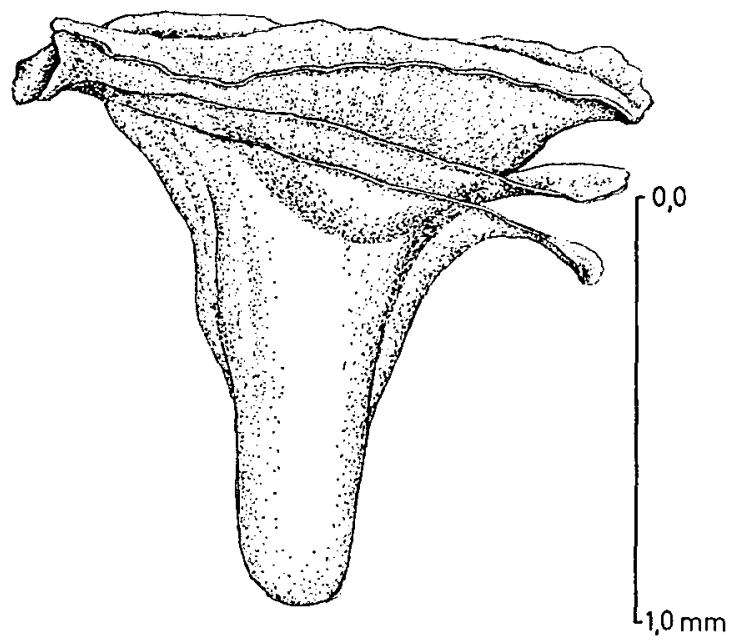

Fig. 7. Stephanoscyphus racemosus, funnel shaped peridermal operculum consisting of several sheets of periderm produced during several successive stages of contraction of the soft body into the tube. Drawn by F. Heckmann.

phenomenon of inactivity there can be no doubt that the climatic conditions and particularly the temperature are the active factors upon which $S$. racemosus depends. The temperature must exert a marked influence on this polyp as it inhabits the very high level near the under border of the eulittoral zone. In winter, the warm Kuroshio current enters Tanabe Bay and compensates the cold climate to some degree. In any case, the existence of the periodicity in activity and inactivity can be explained as a result of adaptation to the changes in temperature.

We can conclude, furthermore, that $S$. racemosus represents an originally tropical species. The former range of distribution must have been in tropical areas with warm water all year round having a small yearly amplitude of minimal and maximal water temperatures. In the true tropical $S$. spec. from the Indian Ocean there exists no periodicity with such a marked inactivity. According to laboratory observations, the phases of strobilation in this species follow at suceessive intervals of 
about 2 or 3 months all year round. Many more observations are needed and planned to elucidate the periodicity of $S$. racemosus, to find out the morphological equivalents and to check corresponding changes in metabolism.

\section{Observations on the regeneration qualities of $S$. racemosus}

As described in a former paper (WERNER 1970 a) it could be shown that the colonial $S$. mirabilis has greater regenerative abilities than the solitary $S$. spec. From comparative observations, the conclusion is that the evolutionary acquisition of ramification and the greater regeneration capacity are correlated with each other and that these two qualities are connected in a causal relation. The well branched species of $S$. racemosus gave the opportunity desired to check that working hypothesis. First experiments were performed in the same way as in S. mirabilis:

(a) Single polyps were detached from the colonies by cutting them near the basic branching point.

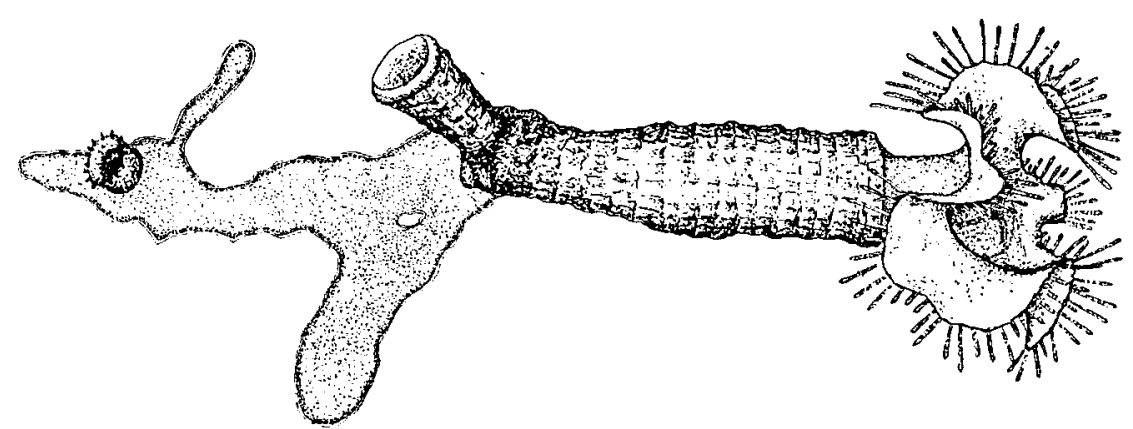

Fig. 8. Stephanoscyphus racemosus, result of the regeneration experiment (a). From the basis of an isolated adult polyp (on the right) a young polyp (contracted) and a scyphorhiza with a developing new polyp are originated. Drawn by F. HEckmann.

(b) A large portion of the soft body was completely taken out of the periderm tube and was isolated without any traces of periderm.

In S. mirabilis, experiment (a) resulted in most cases in a new polyp being produced from the basic aperture. Later on the specimen with two heads grew into a branched colony with numerous heads (see Fig. 2 a, b). In no case could it be observed that at the basic part a new attaching disc had been built up from the outgrowing cell material.

In $S$. racemosus, on the other hand, the same experiment gave a completely different result. In most cases, it resulted in an outgrowth of a complex of undifferentiated cell material from the basic aperture of the isolated polyp (Fig. 8). It forms a flat, irregularly shaped disc of cell material which attaches to the substratum, and which then transforms into a true attaching disc. This basic disc becomes enveloped with a membrane of periderm and produces as a "scyphorhiza" 
new flat stolons from which new polyps will be produced. The regeneration capacity of $S$. racemosus described, corresponds exactly with that of hydroids which possess a hydrorhiza.

If a specimen of the solitary $S$. spec. is cut through, from the under aperture of the upper part no regenerative processes can take place. The only reaction is that the under aperture is closed by cell tissue which then secretes a periderm membrane. The different results of the experiment (a) justify the conclusion that, in the species investigated, there exists a series of increasing regenerative qualities: $S$. spec. $<S$. mirabilis $<S$. racemosus.

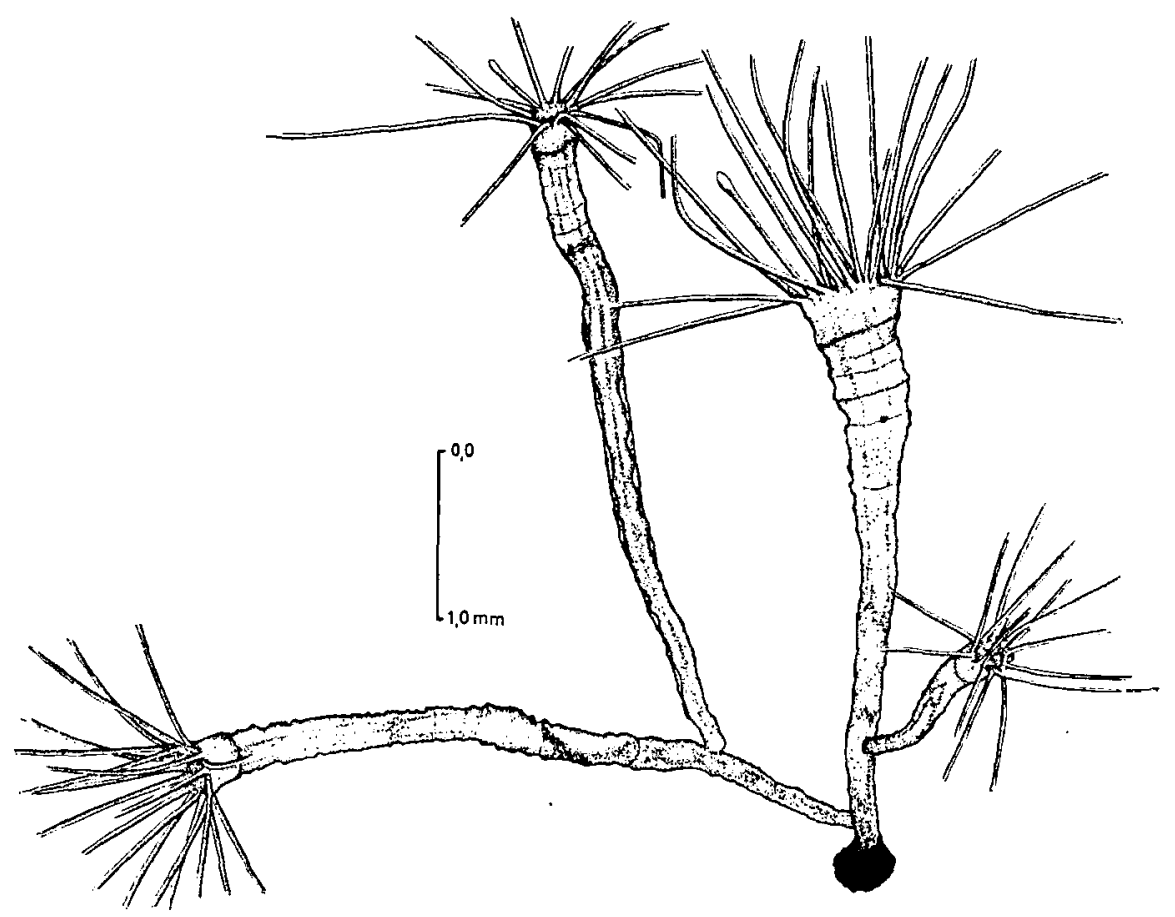

Fig. 9. Stephanoscyphus mirabilis, result of the regeneration experiment (b). From the regeneration body (cell tissue without periderm) a small single basic attaching disc (black) with a new colony of several polyps is originated. Distal parts of tentacles not drawn. Drawn by U. Schreiber.

(b) I have also described (WERNER 1970 a) that in $S$. mirabilis the isolated part of the soft body without periderm is able to develop a new thin peridermal membrane, attach to the substratum and regenerate a small polyp. These processes take place within a period of several weeks. The small polyp is able to produce a new colony with numerous secondary polyps (Fig. 9). Furthermore, it has been shown that the solitary $S$. spec. lacks an adequate ability to regenerate. In this species an isolated fragment of the soft body can also be enveloped by a thin periderm mem- 
brane, but over a long period of several months no regenerative processes have taken place and the fragment finally died.

The regenerative behaviour of the isolated part of the soft body in $S$. racemosus is initiated by a transformation of the body to a more or less globular body, in which the head with the mouth field and tentacles is reduced. This globular body flattens on the underside and attaches to the substratum. The internal cell material of the almost hemispherical body undergoes a complete reorganisation, the result of which

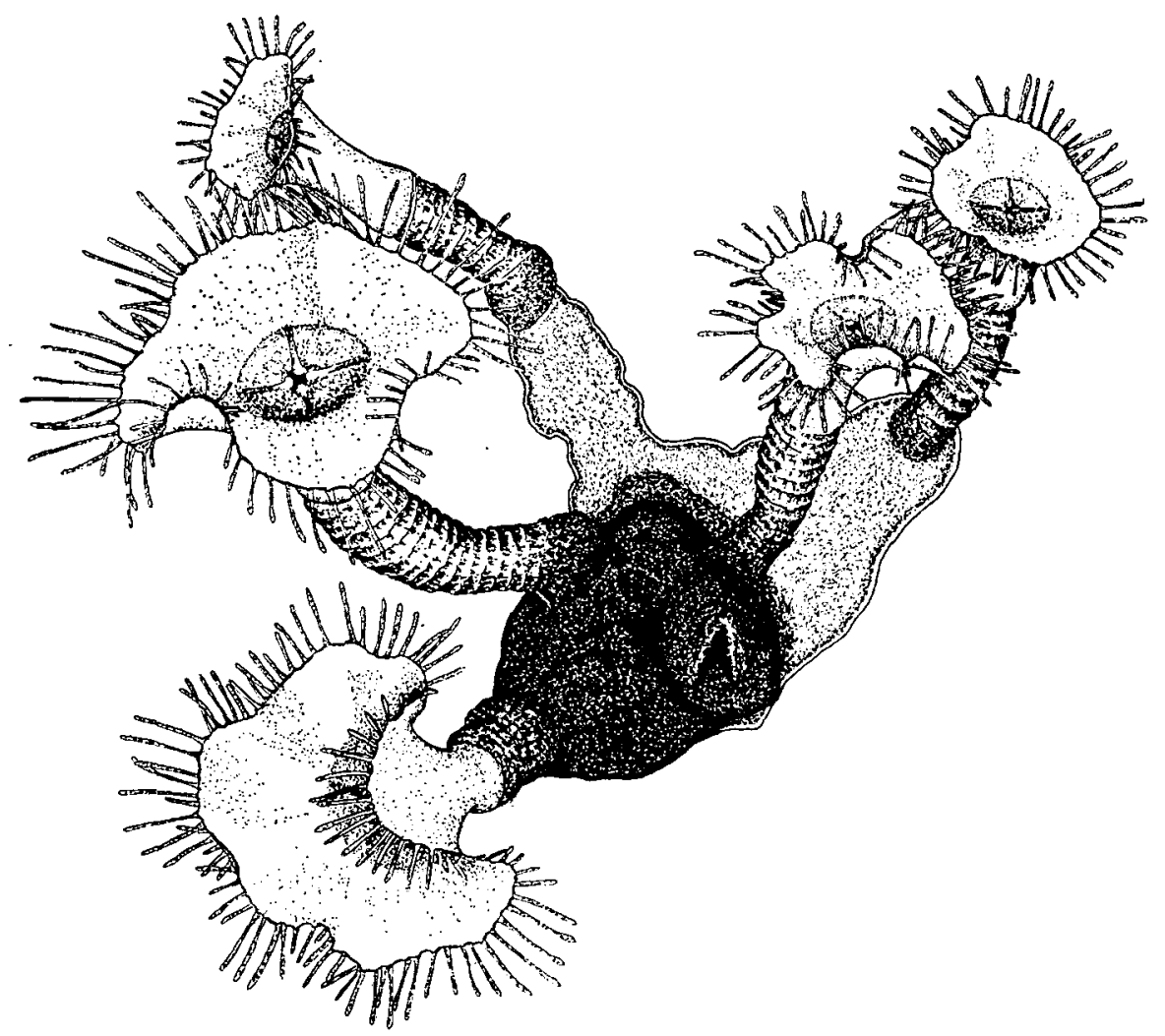

Fig. 10. Stephanoscyphus racemosus, result of the regeneration experiment (b). From the regeneration body (in the center, black) 3 young polyps and a scyphorhiza with 2 polyps are originated. Drawn by F. Heckmann.

(after a resting period of several weeks) is the production of a new small head complete with mouth field and tentacles. The new small polyp is able to feed, grow and originate a new colony with more secondary polyps (Fig. 10).

In these experiments there is a remarkable difference between the behaviours of the regenerating bodies of $S$. mirabilis and $S$. racemosus. In $S$. mirabilis one new polyp only is produced from the basal cell material (Fig. 9). This primary polyp reproduces by branching a new colony. Therefore, in S. mirabilis the complete colony 
stands on the single polyp which was first reproduced from the regeneration body without periderm. In $S$. racemosus from the greater regenerative capacity of the cell material there results a broadening attaching disc as the basic part which can produce new stolonial material. From the new stolons, which form the "scyphorhiza", new secondary polyps grow out.

Thus, also from the experiment (b) it can be concluded that $S$. racemosus possesses higher regenerative qualities than $S$. mirabilis. To date, the experiments on the regenerative capacities of the several species have been made only from the point of qualitative demonstration and to test the principal differences. The investigations need, of course, the exact analysis to obtain also quantitative data, but already from the results hitherto obtained there can be no doubt that $S$. racemosus exhibits the highest regenerative capacities of all species investigated. It seems obvious that really an evolutionary correlation exists between habit and mode of ramification and the regenerative capacities.

\section{Conclusions}

By comparative observations on morphology, anatomical structure and physiological qualities it could be shown that $S$. racemosus represents an interesting mosaic of primitive and progressive characteristics. The outstanding advanced morphological features are the regular mode of ramification, the existence of a scyphorhiza and the shape of the head. The existence of a multiple number of muscle strands is an advanced anatomical feature. Contrary, the only reasonable explanation for the basic tetramerous structure of the soft body with 4 gastral septa and 4 gastral pockets, with the ring canal and the 4 radial canals and, furthermore, the marked tetramerous structure of the head with 4 perradial folds of the border, is that they are inherited from the tetramerous ancestors. It seems also reasonable to consider the production of germ cells in the polyp as a primitive, intermediate stage between the ancestral condition of the sexual polypoid stem form and the conditions prevailing in all other recent scyphozoans, in which the medusae represent the sexual generation. With respect to physiology, the marked seasonal periodicity in the life activities, the symbiosis with zooxanthellae and the high regenerative capacities are facts which indicate the past progressive nature of evolution. In all its characteristics $S$. racemosus has reached the peak of specialisation in the series of evolutive processes which can be traced in the genus Stephanoscyphus. When considering and evaluating the ecological situation of that species it must be concluded that the advanced stage of evolution coincides with special conditions of its habitat.

S. racemosus represents a true littoral form which has invaded the highest sublittoral zone near the under boundary of the eulittoral area. This high zone provides much information on the conditions necessary for the symbiosis with the zooxanthellae. Furthermore, in this zone the general climatic conditions are marked by a wide range of temperature amplitude with a low winter minimum and a high summer 
maximum. Therefore, it seems reasonable to explain the marked seasonal periodicity of the life activity as a progressive step in evolution and as an adaptation to the unstable environmental conditions. Finally, the several species of Stephanoscyphus provide an example of evolutionary speciation in the sea.

These conclusions imply to some extent and in a tentative way the following one that the steps of evolution which have taken place in the polyp generation of Scyphozoa can serve as a model for those which the polyps of Hydrozoa have undergone in the past in a similar way. With regard to this aspect, (a) the diminution in size of the single polyp correlated with the process of ramification, (b) the growth of the basal disc to form a stolonial colony from a hydrorhiza resp. scyphorhiza, and (c) the increased regenerative capacities correlated with ramification are interesting and relevant features. There can be no doubt that these characteristics mark corresponding trends of evolution in the two classes. However, owing to the great variety of forms and to the high degree of radiation in the class Hydrozoa respective steps of evolution from lower to higher levels cannot be traced in a simple way adequate to that in the Scyphozoa.

\section{Summary}

1. Morphology, anatomy and development of 3 different species of Stephanoscyphus: (a) S. spec., a tropical solitary species from the Indian Ocean, (b) S. mirabilis, a colonial species from the Mediterranean, (c) S. racemosus, a colonial species from Seto, Japan, are outlined. The comparison indicates the steps of evolution from solitary to colonial species which has taken place in the genus Stephanoscyphus.

2. The additional notes on the ecology of $S$. racemosus elucidate that the special features of morphology and life history must be explained as a result of adaptation to the conditions for life of a special habitat.

3. Experimental results of the regenerative qualities confirm that S. racemosus has reached the peak of evolutionary progress in the genus Stephanoscyphus.

\section{REFERENCES}

Allman, G.J,, 1874. On the structure and systematic position of Stephanoscyphus mirabilis, the type of a new order of Hydrozoa. Trans. Linn. Soc. Lond. (Ser. 2 : Zool.) 1, 61-66.

Brahm, C. \& Geiger, S.R., 1966. Additional record of the scyphozoan Stephanoscyphus simplex Kirkpatrick. Bull. Sth. Calif. Acad. Sci. 65, 47-52.

Chapman, D.M., 1966. Evolution of the scyphistoma. In: The Cnidaria and their evolution. Ed. by W.J. Rees. Acad. Pr. Lond. (Symp. zool. Soc. Lond. 16, 51-75).

Komar, T., 1935. On Stephanoscyphus and Nausithoë. Mem. Coll. Sci. Kyoto Univ. (Ser. B) 10, 289339.

Komai, T., 1936. On another form of Stephanoscyphus found in the waters of Japan. Mem. Coll. Sci. Kyoto Univ. (Ser. B) 11, 175-183.

Komal, T. and Tokuoka, Y., 1939. Further observations on the strobilation of Stephanoscyphus. Mem. Coll. Sci. Kyoto Univ. (Ser. B) 15, 127-133.

Kramp, P.L., 1959. Stephanoscyphus (Scyphozoa). Galathea Rep. 1, 173-185. 
Leloup, E., 1937. Hydropolypes et Scyphopolypes recueillis par C. Dawydoff sur les côtes de l'Indochine française. Mém. Mus. r. Hist. nat. Belg. (Sér. 2) 12, 1-73.

Lo Bianco, S. and Mayer, P., 1890. Spongicola und Nausithoë. Zool. Anz. 13, 687-688.

Moore, D.R., 1961. The occurrence of Stephanoscyphus corniformis Komal (Scyphozoa) in the western Atlantic. Bull. mar. Sci. Gulf Carib. 11, 319-320.

Moore, R.C. and Harrington, H.J., 1956. Scyphozoa. In: Treatise on invertebrate paleontology. Pt F: Coelenterata. Univ. of Kansas Pr., Lawrence, Kans. 498 pp. (Repr. 1963).

Naumov, D.W., 1959. Artliche Verschiedenheiten der Polypengeneration der Coronatae. (Russ.) Dokl. Akad. Nauk SSSR 126, 902-904.

Remane, A., 1954. Die Geschichte der Tiere. In: Heberer, G., Die Evolution der Organismen. Bd. 1, 340-422. Gustav Fischer, Stuttgart.

ThIEL, Hj., 1966. The evolution of Scyphozoa. A review. In: The Cnidaria and their evolution. Ed. by W.J. Rees. Acad. Pr. Lond. (Symp. zool. Soc. Lond. 16, 77-117).

UchidA, T., 1963. Coelenterata, or Cnidaria. In: The lower Metazoa. Comparative biology and phylogeny. Ed. by E.C. Dougherty. Univ. Calif. Pr., 169-177.

UchiDA, T., 1969. The interrelationships of scyphozoan class. Bull. Mar. Biol. Stat. Asamushi, Tôhoku Univ. 13, 247-250.

Werner, B., 1966. Stephanoscyphus (Scyphozoa Coronatae) und seine direkte Abstammung von den fossilen Conulata. Helgoländer wiss. Meeresunters. 15, 317-347.

Werner, B., 1967a. Morphologie, Systematik und Lebensgeschichte von Stephanoscyphus (Scyphozoa Coronatae), sowie seine Bedeutung für die Evolution der Scyphozoa. In: Verh. dt. zool. Ges. Göttingen 1966, Zool. Anz. Suppl. Bd. 30, 297-319.

Werner, B., 1967b. Stephanoscyphus Allman (Scyphozoa, Coronatae), ein rezenter Vertreter der Conulata ? Paläont. Z. 41, 137-153.

WERner, B., 1970a. Weitere Untersuchungen über die Entwicklungsgeschichte von Stephanoscyphus (Scyphozoa, Coronatae) und seine Bedeutung für die Evolution der Scyphozoa. In: Verh. dt. zool. Ges. Würzburg 1969, Zool. Anz. Suppl. Bd, 33, (in press).

Werner, B., 1970b. Neue Beiträge zur Evolution der Scyphozoa und Cnidaria. In: First international symposium on zoophylogeny. Salamanca, 1969, (in press). 